\title{
REFLEKSI KETERAMPILAN GURU PAUD DALAM PEMBELAJARAN TERPADU
}

\author{
Rizka Fitriani \\ Pengajar LPKIA Kota Ternate
}

\begin{abstract}
Childhood is a period of the most important and critical in the growth and development of life. From an early age, children need to be taught character education and life skills in order to be a good quality of human self. A teacher must collaborate professionalism and creativity with the ability to teach and educate young children so that the brand has a balance of life skills to become independent, self-confidence, responsibility and love of self, family, neighborhood and God.
\end{abstract}

Key word: skill, integrated learning.

\section{PENDAHULUAN}

Masa kanak-kanak merupakan masa yang paling penting dan kritis dalam pertumbuhan dan perkembangan hidup manusia. Pemahaman anak-anak terhadap sesuatu yang konkret pada usia 7 hingga 10 tahun disebutkan oleh piaget sebagai suatu masa concrete operational, dimana anak belajar dan mengamati lingkungan sekitarnya yang bersifat konkrit atau nyata. Masa usia sekolah dasar atau dini juga merupakan masa penting bagi penanaman nilai-nilai kebaikan (basic goodness) pada individu sehingga kelak akan menjadi individu yang berkarakter (man with character). Oleh karena itu, sejak usia dini anak perlu diajarkan pendidikan karakter dan keterampilan hidup yang baik agar kelak menjadi anak manusia yang berkualitas mandiri dan bermoral baik. Namun pola pengajaran pada kebanyakan sekolah dasar yang ada selama ini lebih menekankan pada aspek perkembangan kognitif dan mengesampingkan aspek emosi, moral dan sosial sehingga cenderung menciptakan anak yang mempunyai kemampuan kognitif tinggi tetapi mempunyai kemampuan emosi dan sosial yang rendah. Hal ini dapat diamati dari komposisi mata ajaran yang terdiri dari mata ajaran matematika, bahasa indonesia, PPKN dan agama yang lebih menekankan pada hafalan dan aspek pengetahuan (the knowledge), sementara aspek perasaan (the feeling) dan perilaku (the behavior) diabaikan. Selain itu bentuk evaluasi hasil belajar yang amat berorientasi pada nilai dan ranking justru membuat beban anak untuk belajar semakin berat.

Memperhatikan hal-hal itulah guru pendidikan anak usia dini harus mengkolaborasikan kemampuan profesionalitas dan kreatifitasnya untuk mengajar dan mendidik anak-anak usia dini agar mereka memiliki keseimbangan kecakapan hidup sehingga akan tumbuh menjadi anak yang mandiri, percaya diri dan bertanggung jawab 
serta memiliki kecintaan terhadap diri sendiri, keluarga, lingkungan serta terhadap Tuhan Pencipta Alam Semesta. Berkaca dari tujuan yang hendak dicapai seperti diatas maka guru PAUD diharapkan dapat menyiapkan suasana kelas atau sekolah sesuai dengan tema dan judul kegiatan, sebagai pendukung agar anak semakin tercelup ke dalam tema dan judul kegiatan pembelajaran yang akan berlangsung. Model pembelajaran yang digunakan dalam pengajaran haruslah juga dipilih dengan selektif agar model tersebut bisa membangkitkan gairah belajar anak-anak usia dini secara menyenangkan.

\section{KAJIAN TEORI}

\section{Hakikat Pembelajaran Terpadu}

Pembelajaran terpadu pada anak usia dini dalam hal ini murid SD kelas 1 sampai kelas 6 didasarkan pada keyakinan bahwa anak akan tumbuh dengan baik jika dilibatkan secara alamiah dalam proses belajar.3 Istilah terpadu pada pembelajaran terpadu atau integrated adalah".........repositioning of earning experiences into meaningful contexs"(Collin, et,all, 1991:2). Maksudnya bahwa pembelajaran terpadu menekankan pengalaman belajar dalam konteks yang bermakna.Pembelajaran dalam hal ini bertolak dari tema-tema. Selain itu pembelajaran terpadu didefinisikan juga sebagai : "Suatu konsep dapat dikatakan sebagai pendekatan belajar yang melibatkan beberapa bidang studi untuk memberikan pengalaman yang bermakna pada anak" (CRI Indonesia, 2000:17). Dikatakan bermakna karena dalam pembelajaran terpadu, anak akan memahami konsep yang dipelajari melalui pengalaman langsung dan menghubungkannya dengan konsep lain yang sudah dipahami anak melalui kesempatannya mempelajari apa yang berhubungan dengan tema atau peristiwa otentik (alami). Dalam pembelajaran semacam itu, anak diharapkan selalu mendapatkan kesempatan untuk terlibat secara aktif sesuai dengan aspirasi dan minatnya, dimana dalam pembelajaran terpadu sangat menghargai keragaman.

Pembelajaran terpadu sebagai suatu konsep dapat dikatakan sebagai pendekatan belajar mengajar yang melibatkan beberapa bidang studi untuk memberikan pengalaman bermakna kepada anak didik. Dikatakan bermakna karena dalam pembelajaran terpadu, anak didik akan memahami konsep-konsep yang mereka pelajari itu melalui pengalaman langsung dan menghubungkannya dengan konsep lain yang sudah mereka pahami (Tim BP3GSD, 1996: 5). Kecenderungan pembelajaran terpadu diyakini sebagai pendekatan yang berorientasi pada praktik pembelajaran yang sesuai dengan kebutuhan perkembangan anak (Developmentally Appropriate Practice).Pendekatan ini berangkat dari teori pembelajaran yang menolak driil sebagai dasar pembentukan pengetahuan dan struktur intelektual anak. Para Gestalist adalah tokoh-tokoh yang dirujuk berkenaan dengan pembelajaran yang harus bermakna, di samping juga teori Piaget dan para Kognitivis lain yang menekankan pentingnya program pembelajaran yang berorientasi DAP (Tim BP3GSD, 1996: 5). Jika dibandingkan dengan pendekatan konvensional, pembelajaran terpadu tampaknya lebih 
menekankan keterlibatan anak dalam belajar; membuat anak secara aktif terlibat dalam proses pembelajaran dan pembuatan keputusan. Pendekatan ini lebih mungkin menjadi sesuatu yang dikemukakan oleh John Dewey dengan konsep Learning by Doing-nya (Tim BP3GSD, 1996: 5). Pendekatan pembelajaran terpadu dapat dipandang sebagai upaya untuk memperbaiki kualitas pendidikan di tingkat dasar, terutama dalam rangka mengimbangi gejala penjejalan kurikulum yang sering terjadi dalam proses pembelajaran di sekolah (Tim BP3GSD, 1996: 6). Berdasarkan uraian di atas, maka pengertian pembelajaran terpadu dapat dilihat sebagai berikut.

1) Pembelajaran yang beranjak dari suatu tema tertentu sebagai pusat perhatian (center of interest) yang digunakan untuk memahami gejala-gejala konsep lain, baik yang berasal dari bidang studi yang bersangkutan maupun dari bidang studi lainnya.

2) Suatu pendekatan pembelajaran yang menghubungkan berbagai bidang studi yang mencerminkan dunia nyata di sekeliling dan dalam entang kemampuan dan perkembangan anak.

3) Suatu cara untuk mengembangkan pengetahuan dan keterampilan anak secara simultan.

4) Merakit atau menggabungkan sejumlah konsep dalam beberapa bidang studi yang berbeda dengan harapan anak akan belajar dengan lebih baik dan bermakna.

Antara tema, konsep dan topik menampilkan suatu siklus yang saling terkait melalui lintas pembelajaran. Keterkaitan inilah yang akan dapat menangkap pembelajaran secara utuh dan menyeluruh saat anak berupaya menghubungkan antara konsep, gagasan yang ada pada suatu mata pelajaran ke mata pelajaran lainnya. Di sinilah kunci kesuksesan pembelajaran terpadu.Keberhasilan sangat ditentukan oleh perencanaan dan kemasan guru sesuai dengan kondisi anak didik terkait dengan minat, bakat, kebutuhan dan kemampuan mereka.Topik dan konsep yang ada dalam GBPP sudah tertata sedemikian rupa. Kemampuan guru untuk menyajikan topik dan konsep GBPPlah yang akan menentukan keberhasilan pembelajaran terpadu ini.

Pembelajaran terpadu terjadi apabila kurikulum dapat menampilkan tema yang mendorong terjadinya eksplorasi atau kejadian-kejadian secara autentik dan alamiah. Dengan munculnya tema atau kejadian yang alami ini akan terjadi suatu proses pembelajaran yang bermakna dan materi yang dirancang akan saling terkait dengan berbagai bidang pengembangan yang ada dalam kurikulum. Didalam pembelajaran terpadu terdapat keterkaitan antara satu mata pelajaran dengan mata pelajaran lainnya.Hilda Karli dan Margaretha (2002:15) mengemukakan beberapa ciri pembelajaran terpadu, yaitu sebagai berikut.

1. Holistik, suatu peristiwa yang menjadi pusat perhatian dalam pembelajaran terpadu dikaji dari beberapa bidang studi sekaligus untuk memahami suatu fenomena dari segala sisi.

2. Bermakna, keterkaitan antara konsep-konsep lain akan menambah kebermaknaan konsep yang dipelajari dan diharapkan anak mampu 
menerapkan perolehan belajarnya untuk memecahkan masalah-masalah nyata di dalam kehidupannya.

3. Aktif, pembelajaran terpadu dikembangkan melalui pendekatan diskoveriinquiri. Peserta didik terlibat secara aktif dalam proses pembelajaran yang secara tidak langsung dapat memotivasi anak untuk belajar.

Sejalan dengan pemikiran itu, Tim Pengembang PGSD (1977:7) mengemukakan bahwa pembelajaran terpadu memiliki ciri-ciri berikut ini.

1. Berpusat pada anak

2. Memberikan pengalaman langsung pada anak

3. Pemisahan antara bidang studi tidak begitu jelas

4. Memyajikan konsep dari berbagai bidang studi dalam suatu proses pembelajaran.

5. Bersikap luwes

6. Hasil pembelajaran dapat berkembang sesuai dengan minat dan kebutuhan anak.

Pembelajaran terpadu berlandaskan pada pendekatan inquiry dimana anak dilibatkan dalam merencanakan, berkolaborasi dan berbagi gagasan. Anak-anak didorong untuk berkolaborasi bersama teman-temannya dan pembelajaran dengan cara mereka sendiri. Anak-anak diberdayakan sebagai si pembelajar dan mampu mengejar kebutuhan belajar mereka melalui tema-tema yang dirancang. Dalam artikel ini penulis akan memberikan contoh pembelajaran terpadu menggunakan model pembelajaran webbed atau keterjalaan (jaring laba-laba).

\section{Pengertian Model Pembelajaran Webbed}

Webbed adalah model pembelajaran terpadu yang implementasinya menggunakan pendekatan tematik.Pendekatan ini pengembangannya dimulai dengan menentukan tema-tema tertentu, misalny, Lingkungan. Tema bisa ditentukan dengan negosiasi antara guru dengan siswa, tetapi dapat pula dengan cara diskusi sesama guru. Setelah tema disepakati, kemudian dikembangkan sub-sub temanya dengan memperhatikan kaitan dengan bidang-bidang studi lainnya. Dari sub-sub tema ini dikembangkan aktivitas belajar yang dilakukan oleh siswa. Jadi model webbed atau jaring laba- laba terimplementasi melalui pendekatan tematik sebagai pemandu bahan dan kegiatan pembelajaran. Pendekatan ini adalah model pembelajaran yang digunakan untuk mengajarkan tema tertentu yang cenderung dapat disampailan melalui beberapa bidang study lain. Dalam hubungan ini, tema dapat mengikat kegiatan pembelajaran, baik dalam mata pelajaran maupun lintas mata pelajaran.

\section{Gambaran Model Webbed}

Model webbed ini menekankan pada penerapan konsep belajar sambil melakukan sesuatu (learning by doing). Oleh karena itu guru perlu mengemas atau merancang pengalaman belajar yang berkesan agar belajar siswa lebih bermakna. Pengalaman belajar yang menunjukkan kaitan unsur-unsur konseptual menjadikan 
proses pembelajaran lebih efektif. Selain itu dengan penerapan pembelajaran terpadu model webbed yang menggunakan pendekatan tematik disekolah dasar, akan sangat membantu siswa, karena sesuai dengan tahap perkembangan siswa yang masih melihat segala sesuatu dengan satu kesatuan(holistic).

Model pembelajaran terpadu berdasarkan lintas beberapa disiplin ilmu yang sering digunakan untuk Pendidikan Anak Usia dini adalah model Webbed. Model ini memadukan materi pembelajaran dari beberapa bidang studi dalam satu tema yang memiliki jaringan yang saling berhubungan dalam bentuk jaringan laba-laba (Jamaris, 2004:97).Tegasnya, Pembelajaran Terpadu merupakan sebuah pembelajaran yang menekankan agar seorang guru lebih kreatif.Kreativitas yang dimiliki seorang guru ini sebagai salah satu solusi penerapan dan pengembangan pembelajaran terpadu disekolah dasar yang sampai saat ini belum dapat diaplikasikan disetiap sekolah dasar.Guru juga harus lebih aktif dan mampu memanfaatkan perkembangan IPTEK untuk mengembangkan model pembelajaran serta memanfaatkan media dan lingkungan sehingga mampu mengaplikasikan pembelajaran terpadu di sekolah dasar.

Beberapa karakteristik Model Webbed antara lain:

Berpusat pada siswa

Pendekatan ini lebih banyak menempatkan siswa sebagai subjek belajar, sedangkan guru lebih banyak berperan sebagai fasilitator yaitu dengan menberikan kemudahankemudahan kepada siswa untuk melakuakan aktivitas belajar.

Memberi pengalaman langsung

Dengan pengalaman langsung, siswa dihadapkan pada sesuatu yang nyata/konkrit sebagai dasar untuk memahami hal-hal yang lebih abstrak.

Pemisahan mata pelajaran yang tidak begitu jelas

Fokus pembelajaran diarahkan kepada pembahasan tema-tema yang paling dekat berkaitan dengan kehidupan siswa.

Menyajikan konsep dari berbagai mata pelajaran

Menyajikan konsep-konsep dari berbagai mata pelajaran dalam suatu proses pembelajaran. Dengan demikian siswa mampu memahami konsep-konsep tersebut secara utuh. Hal ini deperlukan untuk membantu siswa dalam memecahkan masalah yang dihadapi sehari-hari.

Bersifat Fleksibel

Guru dapat mengkaitkan bahan ajar dari satu mata pelajaran dengan mata pelajaran lain, bahkan mengkaitkan mata pelajaran dengan kehidupan siswa dan keadaan lingkungan sekolah dimana meraka berada.

Hasil pembelajaran sesuai dengan minat dan bakat siswa.

Menggunakan prinsip belajar sambil bermain yang menyenangkan.

\section{Langkah Membuat Rancangan Model Webbed}

Dengan penerapan pembelajaran terpadu model webbed yang menggunakan pendekatan tematik disekolah dasar akan sangat membantu siswa, karena sesuai dengan tahap perkembangan siswa yang masih melihat segala sesuatu sebagai satu 
kesatuan (holistik). Langkah untuk membuat rancangan pembelajaran terpadu dengan model jaring laba-laba yaitu:

1. Mempelajari kompetensi dasar, hasil belajar dan indikator setiap bidang pengembangan untuk masing-masing kelompok usia.

2. Mengidentifikasi tema dan subtema dan memetakannya dalam jaring tema.

3. Mengidentifikasi indikator pada setiap kompetensi bidang pengembangan melalui tema dan subtema.

4. Menentukan kegiatan pada setiap bidang pengembangan dengan mengacu pada indikator yang akan dicapai dan subtema yang dipilih.

5. Menyusun Rencana Kegiatan Harian.

\section{Penerapan Model Webbed}

Pembelajaran terpadu menggunakan model webbed dimulai dengan menentukan tema. Sebagai contoh tema yang sudah ditentukan bersama adalah "Diri Sendiri". Dari tema ini dikembangkan dan dipadukan menjadi sub-sub tema yang ada pada beberapa mata pelajaran, misalnya :

\section{Tema : Diri Sendiri \\ Judul : Aku Masuk Sekolah \\ Bahasa Indonesia \\ -Memperkenalkan diri \\ -Bercakap dan menyapa \\ -Mendengarkan cerita}

Matematika

-Menghitung jari

bunga

-Menghitung teman

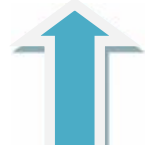

- Menggambar wajah

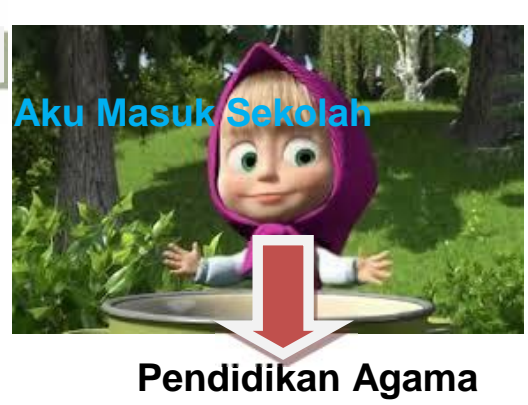

-Mengucapkan salam

-Kalimat tayyiba

-Bersuci/berwudhu

\section{Kertakes}

- Menggambar

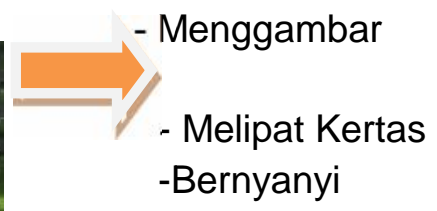

Sebelum masuk kegiatan lakukan "pengkondisian atau ice breaking" misalnya guru melakukan permainan atau games sederhana. Masing-masing anak diminta untuk maju memperenalkan diri kepada teman-teman barunya. Guru dapat memberi contoh 
kepada anak cara memperkenalkan nama, ciri-ciri diri, kesukaan, hobi, alamat rumah dan keluarga. Guru dan teman dapat menggali dan mengarahkan anak untuk dapat mengungkapkan dirinya secara utuh, jelas dan percaya diri. Guru juga mempersilahkan anak untuk bertanya pada teman yang maju di depan kelas setelah temannya memperkenalkan diri. Kegiatan ini dimaksudkan untuk melatih keberanian, kreatif, percaya diri, kepedulian, sopan santun dan toleransi.

\section{PENUTUP}

Pembelajaran terpadu merupakan suatu pendekatan dalam pembelajaran yang secara sengaja mengaitkan beberapa aspek baik dalam intra mata pelajaran maupun antar mata pelajaran yang pelaksanaannya dilakukan secara terpadu, misalnya mata pelajaran Matematika, Bahasa Indonesia, kertakes dan pendidikan agama dipadukan menjadi satu sehingga tercipta satu pokok pembelajaran atau tema. Maka dari itu, dengan adanya metode ini, siswa akan memperoleh pengetahuan dan ketrampilan secara utuh sehingga pembelajaran menjadi bermakna bagi siswa. Selain itu metode ini juga memiliki kelemahan - kelemahan yang harus kita perhatikan, antara lain kecenderungan pemilihan tema yang terlalu dangkal membuat materi yang kita sampaikan menjadi kurang bermanfaat bagi siswa. Model Webbed ini akan berguna jika diterapkan pada kelas rendah karena sesuai dengan tahap perkembangan siswa yang masih melihat segala sesuatu sebagai satu kesatuan (holistic).

\section{Daftar Pustaka}

Atan, H. (2009, June 14). Teo-Education.com. Retrieved January 22, 2013, from TeoEducation.com: http://www.teo-education.com/teo/

BPS/Badan Pusat Statistik dan Depsos/Departemen Sosial, Penduduk Fakir Miskin Indonesia 2002. Jakarta: BPS

Hamalik, Oemar. 1991. Kurikulum dan Pembelajaran. Bandung: Bumi Aksara

Indrawati. 2009. Model Pembelajaran Terpadu Di Sekolah Dasar. Jakarta: Pusat Pengembangan dan Pemberdayaan Pendidik dan Tenaga Kependidikan IImu Pengetahuan Alam (PPPPTK IPA).

Jamaris, Martini. 2004. Pembelajaran Terpadu dan aplikasinya di Taman Kanakkanak.Jakarta : Jurnal Pendidikan Anak Usia Dini,PPS vol 2 No 2, UNJ

Joni, R. 1996. Pembelajaran Terpadu, Makalah Untuk Program Pelatihan Guru Pamong. Jakarta: Depdikbud 